\title{
Pulmonary endocrine cells of Aymara Indians from the Bolivian Andes
}

\author{
D Williams, D Heath, J Gosney, J Rios-Dalenz
}

\begin{abstract}
Introduction There is evidence to suggest that life at high altitude causes changes in the population of pulmonary endocrine cells, possibly because of exposure to chronic hypoxia. A study was made of the populations of pulmonary endocrine cells in three Aymara Indians and three Mestizos of La Paz (3600 m), Bolivia, which were compared with those in four white lowlanders.

Methods Pulmonary endocrine cells were immunolabelled for neurone specific enolase and their two major secretory products, gastrin releasing peptide and calcitonin, and their numbers expressed per $\mathrm{cm}^{2}$ of tissue section.

Results No differences in morphology, number, content, or distribution of immunoreactive cells were found when the native highlanders were compared with the lowlanders.

Conclusions If chronic hypoxia as such exerts an influence on human pulmonary endocrine cells it was not apparent in this morphological study. There was no increase in gastrin releasing peptide containing pulmonary endocrine cells, such as have previously been seen in patients with pulmonary hypertension characterised by plexogenic pulmonary arteriopathy. This may be due to the fact that in plexogenic pulmonary arteriopathy there is free migration of smooth muscle cells. Although three of the highlanders in this present study showed pulmonary vascular remodelling, this was in contrast only modest.
\end{abstract}

(Thorax 1993;48:52-56)

Department of Pathology, Royal Liverpool University Hospital, Liverpool L69 3BX

D Williams

D Heath

J Gosney

Department of

Pathology, San Andres

University, La Paz,

Bolivia

J Rios-Dalenz

Reprint requests to: Dr D Williams

Received 24 February 1991

Returned to authors

10 April 1992

Revised version received

9 July 1992

Accepted 22 July 1992 hypobaric hypoxia of natural high altitude might be expected to affect the function, morphology, content, or distribution of these cells. The aim of this study was to see whether any such changes were apparent in the lungs of a group of Aymara Indians collected during an expedition to the Bolivian Andes.

\section{Methods}

REGION OF STUDY

Obtaining permission and facilities for the performance of necropsies presents difficulties in the Andes and a study such as that presented here has to be carried out in a pathology laboratory at very high altitude adjacent to a hospital providing a service in morbid anatomy. Very few areas meet these requirements. One that does is $\mathrm{La} \mathrm{Paz}$, the capital of Bolivia, which is situated on the eastern slopes of the Andean range. There is considerable variation in the elevation of its various districts. The highest point is the airport, El Alto, at an altitude of $4120 \mathrm{~m}$, and the lowest comprises the nearby jungle valleys at about $3200 \mathrm{~m}$; the central plaza is at $3600 \mathrm{~m}$ and may be taken as an average for the city. We were privileged to receive lung tissue for study from the Obrero Hospital and the Hospital of the University of San Andres.

\section{SUBJECTS}

We studied 10 subjects, in the age range 15-42 years (table 1). Six had been born in $\mathrm{La} \mathrm{Paz}$, or were long standing residents, and were free of cardiopulmonary disease at death. Although all had died in hospital in $\mathrm{La} \mathrm{Paz}$, it was important to ascertain both the altitude of their birthplace and their normal place of residence, as in a large and busy city such as $\mathrm{La} \mathrm{Paz}$ not everyone dying at high altitude is native to the area. Consequently, ethnic origin was considered important. Its definition was that used in the 1976 Bolivian census. ${ }^{5}$ Individuals were classified as "Indian" if they had an Aymara surname, had emigrated to La Paz from a rural community, and lived in a predominantly Indian neighbourhood. Those termed "Mestizo" had a mixed Spanish and Indian family history and had lived in La Paz for at least one generation. The surname in the Mestizo group could be either Spanish or Aymara. By these criteria three of our highlanders were Aymara Indians and three were Mestizos. The four remaining subjects, who constituted a control group, were white lowlanders (cases 7-10, table 1). These also died without any cardiopulmonary disease. innervated and consequently have been termed "neuroepithelial bodies""; others are probably merely aggregates of solitary cells. Experimental evidence has suggested that, in acute hypoxia at least, neuroepithelial bodies act as chemoreceptors monitoring oxygen tension in the airways. ${ }^{2-4}$ Hence chronic exposure to the

Clear cells in the epithelium of many organs the epithelium of bronchi and bronchioles and to a lesser extent in alveolar walls. They are found as single cells or in groups. Some of these 
Table 1 Age, sex, ethnic background, and diagnosis at necropsy

\begin{tabular}{|c|c|c|c|c|}
\hline Case no & Age (y) & Sex & Ethnic background & Diagnosis at necropsy \\
\hline \multicolumn{5}{|c|}{ HIGH ALTITUDE } \\
\hline 1 & 28 & $\mathbf{M}$ & Aymara & Cerebellar tumour \\
\hline 2 & 37 & $M$ & Aymara & $\begin{array}{l}\text { Peritonitis: ruptured } \\
\text { appendix }\end{array}$ \\
\hline 3 & 42 & $\mathbf{M}$ & Aymara & Gastric lymphoma \\
\hline 4 & 15 & $\mathrm{~F}$ & Mestizo & Lupus erythematosus \\
\hline 5 & 27 & $\mathrm{~F}$ & Mestizo & Pyelonephritis \\
\hline 6 & 32 & $\mathrm{M}$ & Mestizo & Pyelonephritis \\
\hline \multicolumn{5}{|c|}{ SEA LEVEL } \\
\hline 7 & 21 & $\mathbf{M}$ & Caucasian & Road accident \\
\hline 8 & 29 & $\mathrm{~F}$ & Caucasian & Friedreich's ataxia \\
\hline 9 & 23 & $\mathbf{M}$ & Caucasian & Road accident \\
\hline 10 & 24 & $\mathbf{M}$ & Caucasian & Road accident \\
\hline
\end{tabular}

LUNG TISSUE

Lungs were distended with $10 \%$ neutral buffered formalin until the pleural surfaces were smooth. Because only a limited amount of tissue could be brought back from La Paz care was taken to ensure, so far as possible, that pulmonary sampling was consistent in its site in all subjects studied from both altitudes. Thus tissue was taken from a point midway between the hilum and the pleural surface such that intrapulmonary bronchi and terminal bronchioles, the sites of greatest concentration of human pulmonary endocrine cells, ${ }^{22}$ were well represented; but more distal airways and pulmonary parenchyma were also included. In most cases eight blocks of tissue were taken from each of the three lobes of the right lung; but in case 5 difficulty in distending the right lung made it necessary to use the left, and eight blocks of tissue were taken from both lobes. These blocks were processed, embedded in paraffin wax and sections cut at a thickness of $4 \mu \mathrm{m}$.

\section{IMMUNOLABELLING}

These sections were labelled for neurone specific enolase (NSE), gastrin releasing peptide (GRP), and calcitonin by the avidin biotin complex technique. Antisera were obtained from Dako Ltd (NSE and calcitonin) and Cambridge Research Biochemicals (GRP). After being dewaxed and taken to absolute alcohol the sections were pretreated with $1 \%$

Table 2 Numbers of pulmonary endocrine cells per $\mathrm{cm}^{2}$

\begin{tabular}{|c|c|c|c|}
\hline \multirow[b]{2}{*}{ Case no } & \multicolumn{3}{|c|}{ Immunoreactive cells $/ \mathrm{cm}^{2}$} \\
\hline & $N S E$ & $G R P$ & Calcitonin \\
\hline \multicolumn{4}{|c|}{ HIGH ALTITUDE } \\
\hline 1 & $5 \cdot 0$ & 4.0 & 0.3 \\
\hline 2 & $4 \cdot 2$ & $3 \cdot 7$ & $0 \cdot 2$ \\
\hline 3 & $4 \cdot 0$ & $3 \cdot 3$ & $0 \cdot 1$ \\
\hline 4 & $3 \cdot 5$ & $3 \cdot 4$ & $0 \cdot 2$ \\
\hline 5 & $3 \cdot 8$ & $3 \cdot 5$ & $0 \cdot 2$ \\
\hline 6 & $4 \cdot 7$ & $4 \cdot 4$ & $0 \cdot 2$ \\
\hline Mean (SD) & $4 \cdot 2(0 \cdot 5)$ & $3 \cdot 7(0 \cdot 4)$ & $0 \cdot 2(0 \cdot 06)$ \\
\hline \multicolumn{4}{|l|}{ SEA LEVEL } \\
\hline 7 & $6 \cdot 8$ & $6 \cdot 5$ & $0 \cdot 2$ \\
\hline 8 & $20 \cdot 3$ & $15 \cdot 6$ & $4 \cdot 5$ \\
\hline 9 & $7 \cdot 2$ & $7 \cdot 0$ & 0.3 \\
\hline 10 & $10 \cdot 4$ & $10 \cdot 0$ & $0 \cdot 2$ \\
\hline Mean (SD) & $11 \cdot 2(5 \cdot 5)$ & $9 \cdot 8(3.6)$ & $1.3(1.9)$ \\
\hline
\end{tabular}

NSE_-neurone specific enolase; GRP_gastrin releasing peptide.

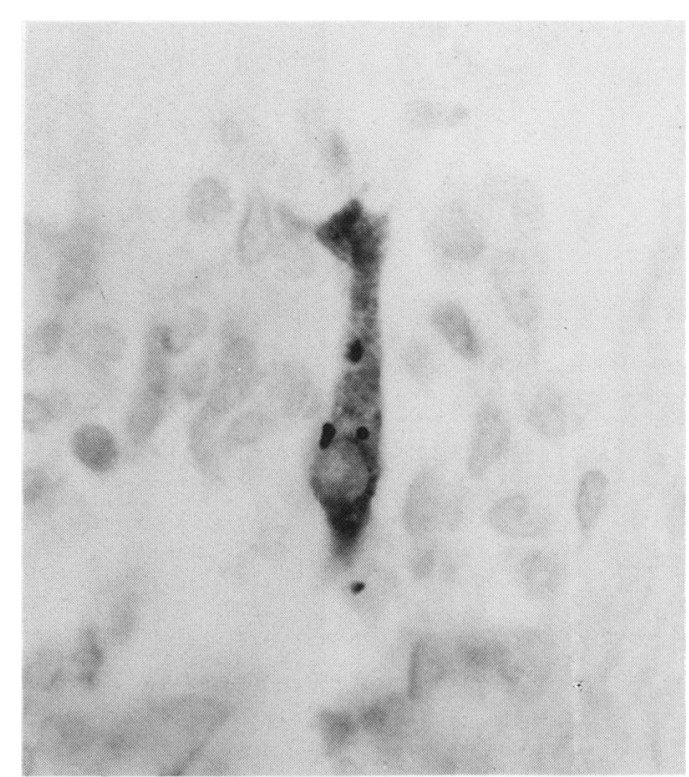

Figure 1 Case 1: Solitary pulmonary endocrine cell of characteristic shape immunoreactive for gastrin releasing peptide. (Avidin-biotin complex method, anti-gastrin releasing peptide.)

hydrogen peroxide in methanol for 20 minutes and with normal swine serum for 20 minutes. This prevented false positive staining due to endogenous peroxide and non-specific binding of immunoglobulin respectively. The primary antisera were applied at optimum dilution (neurone specific enolase at 1:2000, gastrin releasing peptide at 1:4000, calcitonin at 1:2000) and incubated for one hour, after which sections were washed in buffered saline. A biotinylated anti-rabbit secondary antibody was applied at a dilution of 1:200 for 30 minutes. Stabilised avidin-biotin complex (Dako Ltd) was applied to the sections for 30 minutes, after which they were again washed in buffered saline. The chromogen used was diaminobenzidine, which after the addition of hydrogen peroxide produces a black-brown reaction product at antigenic sites. Positive

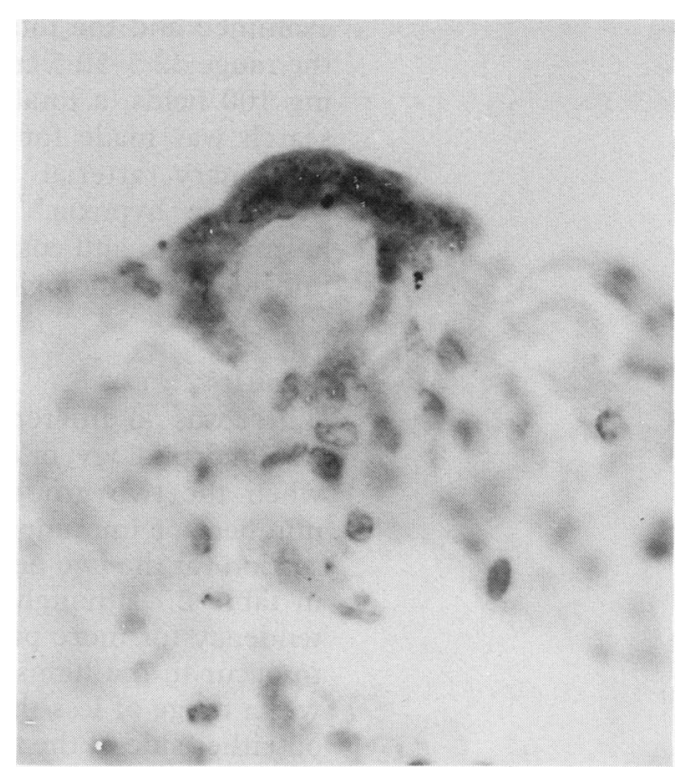

Figure 2 Case 1: Cluster of endocrine cells immunoreactive for gastrin releasing peptide. (Avidinbiotin complex method, anti-gastrin releasing peptide.) 


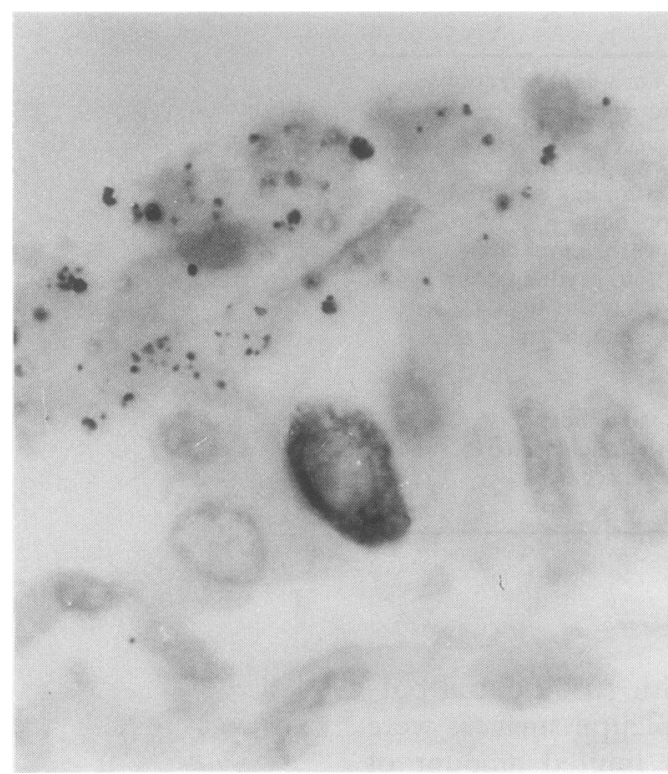

Figure 3 Case 4: Single endocrine cell immunoreactive for calcitonin. (Avidin-biotin complex method, anticalcitonin.

tissue controls included immunolabelling of human fetal lung (gastrin releasing peptide), human medullary carcinoma of the thyroid (calcitonin), and human pancreas (neurone specific enolase). In the negative control procedures labelling was carried out after replacement of the primary antiserum with non-immune serum and after omission of each stage of the procedure in turn. Sections adjacent to those used for immunochemistry were stained by the elastic van Gieson method and with haematoxylin and eosin.

\section{CELL COUNTING}

The numbers of immunoreactive cells in each section were counted by using a microscope fitted with an eyepiece graticule of 100 squares. After calibration by means of a stage micrometer this enabled both the number of cells to be counted and the area of a section to be measured. The whole of a section was examined and the total area measured was in the range $32 \cdot 5-50.5 \mathrm{~cm}^{2}$ per case, $1 \mathrm{~cm}^{2}$ yielding 100 fields, a total of 3250-5050 fields. A search was made for the remodelling of the pulmonary arterial tree that is seen in hypobaric hypoxia. ${ }^{67}$ Sections stained with haematoxylin and eosin served to exclude any undisclosed pathological changes.

\section{Results}

There was no difference in numbers, distribution, morphology, or content of endocrine cells when the two groups were compared. The numbers of immunoreactive cells per $\mathrm{cm}^{2}$ of section for the two peptides studied are shown in table 2. Although there appeared to be a tendency for more pulmonary endocrine cells to occur in the lungs of the lowlanders, there was a range of less than 2 standard deviations on either side of the means and so both sets of data came under the same distribution curve. In the lungs of both groups nearly all cells were solitary (fig 1) and usually in the epithelium of bronchi and bronchioles; only one cluster of cells was seen and it was in an alveolar duct (fig 2). Solitary cells had the shape and situation typical of pulmonary endocrine cells in normal mammalian lungs. They were usually elongated in shape with a round, basal nucleus and located on the basement membrane (fig 1). Most contained gastrin releasing peptide, calcitonin containing cells comprising a much smaller population (table 2, fig 3). All cells that were labelled for one or other of these secretory products (there was no evidence of co-storage) were neurone specific enolase positive, but occasional neurone specific enolase immunoreactive cells contained neither.

All three Aymaras (cases 1-3) showed muscularisation of their pulmonary arterioles, and in addition case 1 showed intimal longitudinal muscle and the formation of inner muscular tubes. ${ }^{67}$ There were no abnormalities of the pulmonary arterial tree in cases $4-6$ or in the lungs of the lowlanders.

\section{Discussion}

Although acute exposure to hypoxia undoubtedly induces activity in neuroepithelial bodies in rabbits, ${ }^{348}$ the effects of chronic hypoxia are uncertain. Studies on animals in the laboratory, where hypoxia has been induced by using hypobaric chambers, have produced contradictory results. ${ }^{9-15}$ This may be due to a combination of factors, including variability in experimental conditions, differences in species or strain susceptibility, ${ }^{15}$ and the fact that the changes induced by hypoxia may be subtle, requiring careful study for their detection. ${ }^{1617}$

Studies at natural high altitude have produced similarly variable results. ${ }^{18-21}$ Rabbits native to the Peruvian Andes and thus exposed all their lives to hypobaric hypoxia were reported to show increased clusters of argyrophilic cells in the lung, ${ }^{18}$ but we were unable to find such an effect in various animal species in the Himalaya of Ladakh. ${ }^{19}$ We studied the pulmonary endocrine cells of sheep, goats, and the yak, together with the yak's interbreeds with cattle (the dzo and stol) at Sakti (4500 m) and compared them with those of sheep and goats at Srinagar $(1590 \mathrm{~m})$. There were no differences in their number or distribution, as shown by immunolabelling with neurone specific enolase, that could be ascribed to the effects of hypobaric hypoxia, though species differences were substantial. More recently guinea pigs from the Peruvian Andes have been shown to have significantly more clusters of pulmonary endocrine cells than controls from sea level, whereas there was no difference in the number of solitary cells. ${ }^{20}$

In an abstract Memoli et $a^{21}$ reported that in six of 20 samples of lung from native highlanders of Bolivia, who had spent their entire lives at altitudes ranging from 3500 to $4300 \mathrm{~m}$, there were significantly more neuroepithelial bodies, as identified by neurone specific enolase, than in a group from sea level. The present study, however, is the first in which individual peptides have been investigated in such subjects. In the normal adult lung endocrine 
cells contain predominantly gastrin releasing peptide and calcitonin, ${ }^{22}$ especially the former.

The absence of discernible differences between the two groups of subjects in the present study may simply be because numbers were too small, or because any changes that had occurred in the highlanders were too subtle to be detected by the methods we used. Furthermore, we cannot entirely exclude the possibility that differences in endocrine cell numbers were present in those parts of the lung that we did not sample-namely, the extrapulmonary and large intrapulmonary bronchi and subpleural parenchyma. Any such difference, however, would be likely to be most apparent in that part of the lung most richly populated with endocrine cells, the intrapulmonary bronchi and terminal bronchioles, ${ }^{22}$ which we were careful to include in the tissue we took.

We are confident that there was no increase in endocrine cell clusters in the subjects from La $\mathrm{Paz}$, as has been reported in previous studies in man $^{21}$ and animals ${ }^{18}{ }^{20}$ from high altitude, when hypoxia has been postulated as its cause.

The lack of any apparent proliferation of gastrin releasing peptide containing cells in the lungs of the highlanders contrasts with the situation in subjects with plexogenic pulmonary arteriopathy due to primary pulmonary hypertension or secondary to congenital cardiac shunts. ${ }^{2324}$ In these conditions, particularly when associated with cellular plexiform lesions and especially in the preplexiform phase, when migration of vascular smooth muscle cells from the media to the intima is at its height, ${ }^{25}$ gastrin releasing peptide containing cells are abundant. A similar association has been described in subacute infantile mountain sickness in Tibet. ${ }^{26}$ This condition is a manifestation of a failure of initial acclimatisation to high altitude in Han infants taken up to reside in Lhasa, and is also characterised by migration of smooth muscle cells from the media to the intima and a prominence of gastrin releasing peptide containing endocrine cells.

Possibly these findings are related to the role of gastrin releasing peptide as a trophic agent. It has been shown to stimulate the growth of normal human bronchial epithelial cells in vitro $^{27}$ as well as murine fibroblasts. ${ }^{28}$ It increases the incorporation of tritiated thymidine into developing bronchial epithelium of fetal mouse lungs in utero and in vitro and of human fetal lung in organ culture. ${ }^{29}$

In Aymara Indians we have studied previously ${ }^{6}$ and in the present study we have found remodelling of the pulmonary arterial tree but with only limited migration of medial vascular smooth muscle cells into the intima. In the present study we could not find an association between the migration of smooth muscle cells and prominence of gastrin releasing peptide containing cells. This may be because the remodelling of the pulmonary arterial tree that had occurred in the Aymara Indians is characterised by only limited migration of smooth muscle cells. ${ }^{67}$

Increased numbers of calcitonin containing endocrine cells seem to be most strongly associated with inflammation, ${ }^{14}{ }^{30}$ which was not a feature of the lungs examined in the present study. Proliferation of such cells does occur in its absence ${ }^{2324}$ and may in some way be associated with a more generalised disturbance in the structure and function of the pulmonary endocrine system.

1 Feyrter F. Über diffuse endokrine epitheliale Organe. Leipzig: Barth, 1938.

2 Lauweryns JM, Cokelaere $M$, Theunynck P. Neuroepithelial bodies in the respiratory mucosa of various mammals: A light optical, histochemical and ultrastructural investigation. $Z$ Zellforsch Mikrosk Anat 1972;135 569-92.

3 Lauweryns JM, Cokelaere M, Deleersnyder M, Liebens $M$ Intrapulmonary neuro-epithelial bodies in new-born rabbits. Influence of hypoxia, hyperoxia, hypercapnia, nicotine, reserpine, L-DOPA and 5-HTP. Cell Tissue Res 1977;182:425-40.

4 Lauweryns JM, de Bock V, Guelinckx D, Decraymer M. Effects of unilateral hypoxia on neuroepithelial bodies in rabbit lungs. J Appl Physiol 1983;55:1665-8.

5 Bolivian Instituto Nacional de Estadistica. Resultados de censo nacional del poblacion y vivienda. Vol 2. La Paz, Bolivia: Ministerio de Planeamiento y Coordinacion, 1976.

6 Heath D, Williams D, Rios-Dalenz J, Calderon M, Gosney J. Small pulmonary arterial vessels of Aymara Indians from the Bolivian Andes. Histopathology 1990;16:565-71.

7 Heath D, Williams D. Pulmonary vascular remodelling in a high-altitude Aymara Indian. International Journal of Biometeorology 1991;35:203-7.

8 Lauweryns JM, Cokelaere $M$, Lerut $T$, Theunynck $P$. Cross-circulation studies on the influence of hypoxia and hypoxaemia on the neuroepithelial bodies in young rabbits. Cell Tissue Res 1978;193:373-86.

9 Moosavi H, Smith P, Heath D. The Feyrter cell in hypoxia. Thorax 1973;28:729-41.

10 Hernandez-Vasquez A, Will JA, Quay WB. Quantitative characteristics of the Feyrter (APUD) cells of the neonatal rabbit lung in normoxia and chronic hypoxia. Thorax 1977;32:449-56.

11 Hernandez-Vasquez A, Will JA, Quay WB. Quantitative characteristics of the Feyrter cells and neuroepithelial bodies of the fetal rabbit lung in normoxia and short term hypoxia. Cell Tissue Res 1978;189:179-86.

12 Keith IM, Wiley LA, Will JA. Pulmonary neuroendocrine cells: decreased serotonin fluorescence and stable argyrophil-cell numbers in acute hypoxia. Cell Tissue Res 1981;214:201-5.

13 Keith IM, Will JA. Hypoxia and the neonatal rabbit lung. Neuroendocrine cell numbers, 5-HT fluorescence intensity, and the relationship to arterial thickness. Thorax 1981;36:767-73.

14 Sissons M. Pulmonary endocrine cells in hypoxia. In: Heath D, ed. Aspects of hypoxia. Liverpool: Liverpool University Press, 1986:171, 173.

15 Pack RJ, Barker S, Howe A. The effect of hypoxia on the number of amine-containing cells in the lung of the adult rat. Eur J Respir 1986;68:121-30.

16 Springall DR, Collina G, Barer G, Suggett AJ, Bee D, Polak JM. Increased intracellular levels of calcitonin generelated peptide-like immunoreactivity in pulmonary endocrine cells of hypoxic rats. J Pathol 1988;155:259-67.

17 McBride JT, Springall DR, Winter RJ, Polak JM. Quantitative immunocytochemistry shows calcitonin generelated peptide-like immunoreactivity in lung neuroendocrine cells is increased by chronic hypoxia in the rat. Am J Respir Cell Mol Biol 1990;3:587-93.

18 Taylor $W$. Pulmonary argyrophil cells at high altitude. $J$ Pathol 1977;122:137-44.

19 Gosney J, Heath D, Williams D, Deen M, Harris P, Anand I, et al. Pulmonary endocrine cells in various species in the Himalaya. J Comp Pathol 1988;99:93-100.

20 Gosney JR. Pulmonary endocrine cells in native Peruvian guinea-pigs at low and high altitude. J Comp Pathol 1990;102:7-12.

21 Memoli VA, Linnoila I, Warren WH, Rios-Dalenz J, Gould VE. Hyperplasia of neuroendocrine cells and neuroepithelial bodies [abstract]. Lab Invest 1983;48:57A.

22 Gosney JR. Sissons MCJ, Allibone RO. Neuroendocrine cell populations in normal human lungs: a quantitative study. Thorax 1988;43:878-82.

23 Gosney J, Heath D, Smith P, Harris P, Yacoub $M$. Pulmonary endocrine cells in pulmonary arterial disease. Arch Pathol Lab Med 1989;113:337-41.

24 Heath D, Yacoub M, Gosney JR, Madden B, Caslin AW, Smith P. Pulmonary endocrine cells in hypertensive pulmonary vascular disease. Histopathology 1990;16:21-8. 25 Heath D, Smith P, Gosney J. Ultrastructure of early 
plexogenic pulmonary arteriopathy. Histopathology 1988;12:41-52.

26 Heath D, Harris P, Sui GJ, Liu YH, Gosney J, Harris E, et al. Pulmonary blood vessels and endocrine cells in subacute infantile mountain sickness. Respir Med 1989;83:77-81.

27 Willey JC, Lechner JF, Harris CC. Bombesin and the Cterminal tetradecapeptide of gastrin-releasing peptide are growth factors for normal human bronchial epithelial cells. Exp Cell Res 1984;153:245-8.
28 Rozengurt E, Sinnett-Smith J. Bombesin stimulation of DNA synthesis and cell division in cultures of Swiss 3T3 cells. Proc Natl Acad Sci USA 1983;80:2936-40.

29 Sunday ME, Hua J, Dai HB, Nusrat A, Torday AS Bombesin increases fetal lung growth and maturation in utero and in organ culture. Am J Respir Cell Mol Biol 1990;3:199-205.

30 Gosney JR, Sissons MCJ, Allibone RO, Blakey AF. Pulmonary endocrine cells in chronic bronchitis and emphysema. J Pathol 1989;157:127-33. 